Bartın Üniversitesi

Eğitim Fakültesi Dergisi

Cilt 6, Sayı 1, s. 322-335, Şubat 2017

BARTIN - TÜRKIYE

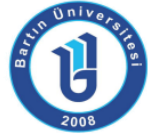

ISSN: 1308-7177
Bartin University

Journal of Faculty of Education

Volume 6, Issue 1, p. 322-335, February 2017

BARTIN - TURKEY

\title{
Okul Müdürlerinin Güçlendirici Liderliğine İlişkin Öğretmen Algısı
}

Necdet KONAN, Doç. Dr., İnönü Üniversitesi Eğitim Fakültesi, necdet.konan@inonu.edu.tr

O. Tayyar ÇELIK, Doktora Öğrencisi İnönü Üniversitesi Eğitim Bilimleri Enstitüsü, , otayyar44@gmail.com

Öz: Bu araştırmanın temel amacı okul müdürlerinin güçlendirici liderliği ne düzeyde sergilediklerine ilişkin öğretmen algılarının belirlenmesidir. Tarama modelinde gerçekleştirilen bu çalışmanın evreni, Malatya ili merkez ilçeleri olan Battalgazi ve Yeşilyurt'taki ilkokul, ortaokul ve liselerde görev yapan 6342 öğretmenden oluşmaktadır. Örneklemini ise evreni temsil eder nitelikte belirlenen 321 öğretmen oluşturmaktadır. Araştırmanın verileri Güçlendirici Liderlik Ölçeği aracılığı ile toplanmıştır. Verilerin analizinde t testi ve tekyönlü varyans analizinden yararlanılmıştır. Araştırma sonucunda, okul müdürlerinin güçlendirici liderliğine ilişkin öğretmen algılarının yüksek düzeyde olduğu, okul müdürlerinin güçlendirici liderliğini erkek öğretmenlerin kadın öğretmenlerden; bir yıl ile dört yıl ve üzeri süreyle okul müdürüyle birlikte çalışan öğretmenlerin iki yıl birlikte çalışan öğretmenlerden daha olumlu algıladıkları; ancak hizmet süresi (kıdem), branş ve okul türü değişkenlerine göre anlamlı farklılık göstermediği belirlenmiştir.

Anahtar Kelimeler: Okul müdürü, liderlik, güçlendirici liderlik

\section{Teacher Perception on the Empowering Leadership of School Principals}

\begin{abstract}
The main purpose of this study is to determine teacher perceptions on what level the school principals exhibit empowering leadership. The population of this study designed in survey model covers 6342 teachers working in primary, secondary and high schools in Battalgazi and Yeşilyurt, the central districts of the province of Malatya. 321 teachers selected to represent this population constitute the sample. Data were collected through the Empowering Leadership Scale. In data analyses were utilized T-test and One-way Analysis of Variance (ANOVA). As a result, it was revealed that teacher perceptions regarding the empowering leadership of school principals are high, male teachers and teachers working with the school principal for one to four years and over perceive the empowering leadership of their school principals more positively than female teachers and teachers working for two years, respectively; however, their perceptions did not significantly differ according to seniority, branch and school type variables.
\end{abstract}

Key Words: School principal, leadership, empowering leadership 


\section{GiRiş}

Örgüte ve yönetime yönelik bilimsel yaklaşımın ortaya çıkmasıyla birlikte farklı kuramlar ve uygulamalarda hızlı bir artış olmuştur. Ancak değişen çevre koşullarıyla birlikte örgütlerin yapısında, liderliğe ve insanın doğasına ilişkin bakış açısında, örgüt ortamında karşılaşılan sorunların niteliğinde ve niceliğinde önemli değişimler yaşanmıştır. Bu sebeple yeni olarak ortaya çıkan birçok kuram ve uygulamanın geçerliği sorgulanır olmuştur. Ayrıca bugünün örgütleri varlıklarını sürdürmek için karmaşık, dinamik ve zor çevre şartlarının üstesinden gelmek zorundadır. Yöneticilerin kendi kendilerine bu sorunlarla başa çıkmaları zor görünmektedir. Örgütsel işleyişi sağlamada örgüt çalışanları da anahtar bir rol oynayabilir. Bu bağlamda günümüz liderlik anlayışı, sorunların üstesinden gelme becerisini astlarına kazandırmış, çalışanları yeterli bilgi ve güçle donatmış bir liderlik anlayışını gerektirmektedir. Güçlendirme, zor ve rekabetçi koşullarla karşı karşıya kalan örgüt üyelerini tekrar harekete geçirmede ve değişimin yıkıcı etkilerine karşı örgüt üyelerini korumada lidere kolaylık sağlayabilir (Conger ve Kanungo, 1988, s. 476).

Yönetim uygulamalarında uzun bir geçmişe sahip güçlendirme kavramına yönelik yoğun bir ilgi bulunmaktadır. Bu ilginin sebebi, güçlendirmenin yönetsel ve örgütsel etkililiği sağlamanın temel bileşenlerinden biri olmasındandır. Ayrıca örgütsel ve yönetsel uygulamalarda yöneticinin güç ve kontrolü astlarıyla paylaşması örgütlerde genel bir üretkenliği ve verimi sağlamada etkili olmaktadır. Elverişli bir süreç olarak güçlendirme, astların göreve yönelik davranışlarını başlatma ve sürdürmede etkilidir (Conger ve Kanungo, 1988, s. 473). Kendi çalışmalarını ve yaşamlarını yönetmek için yeterli güç, yetki ve sorumluluk verilen çalışanlar, yenilikçi olacak ve yöneticiler tarafından sürekli yönlendirilme gereksinimi duymayacaklardır (Kuo vd., 2011, s. 1123).

Liderliğin en fazla ilişkili olduğu kavramlardan birinin güç olduğu; liderliğin güçle ilgisi olduğunu belirtmek yanlış olmasa gerekir. Çünkü güç, genellikle etkileyebilme ve diğerlerini yönlendirebilme yetisi olarak tanımlanmaktadır (Yılmaz, 2011, s. 29). Güçlendirme davranışları üzerine yapılan deneysel ve kavramsal araştırmalardan sonra, 2000'li yıllara doğru güçlendirme bir liderlik biçemi olarak ele alınmaya ve örgütlerde incelenmeye başlanmıştır (Ahaerne vd., 2005; Arnold vd., 2000; Konczak vd., 2000). Güçlendirici liderliğin akademik kökü Ohio State liderlik araştırmalarına, destekleyici liderlik, katılımcı liderlik çalışmalarına ve duruma bağımlıık liderlik kuramları kapsamında yetki devredici, katılımcı ve koçluk edici davranışlar üzerine yapılan çalışmalara dayanmaktadır (Srivastava vd., 2006).

Güçlendirici lider, izleyicilerinin kendiliğinden sorumluluk almasını teşvik eden, kendilerine güvenlerini sağlayan, kendi başlarına hedef belirlemelerine olanak veren, pozitif düşünme olanağı tanıyan ve kendi kendilerine problem çözmeleri için gerekli ortam ve kaynaklarını sağlayarak onları teşvik eden bireylerdir (Yılmaz 2011, s. 140). Ayrıca güçlendirici liderler sorumluluklarını yerine getirebilecekleri ölçüde astlarını yetkilendiren (Arnold, 2000), kişisel ve mesleki gelişimleri, önemli kararlar alabilmeleri için astlarına destek olan (Magni ve Maruping, 2013) liderlerdir.

Güçlendirici liderlik örgüt izleyenlerinin iş motivasyonunu arttıran ve güç paylaşımını kolaylaştıran lider davranışı olarak tanımlanmaktadır (Srivastava vd., 2006, s. 1240). Manz ve Sims (1987) ise güçlendirici bir lideri örgüt çalışanlarının kendi kendine liderlik becerilerini geliştirmelerini teşvik eden lider olarak tanımlar. Güçlendirici liderlik izleyenlere karar vermede, kontrolde, özerklik ve güç yetkisi sağlayarak onları güçlendirme girişimidir. Bu güçlendirme davranışları karşısında izleyenlerin işleriyle ilgili kontrol, bağlılık ve yeterlilik hislerine sahip olması beklenmektedir (Albrecht ve Andreetta, 2011, s. 229). Güçlendirme, 
örgütsel değişimi başlatma ve yönetme girişiminde lidere önemli bir etki aracı olarak katkı sağlayabilir (Conger ve Kanungo, 1988, s. 476).

Güçlendirici liderlik, izleyenleri etkilemede konumun verdiği güce dayalı olarak dönüşümcü ve işlemsel liderlikten ayrılmaktadır. Dönüşümcü liderlik ilham verici motivasyona, entelektüel uyarıma ve bireyselleştirilmiş koşullara dayanmaktadır (Jung ve Sosik, 2002, s. 317). Dönüşümcü liderliğin aksine işlemsel liderlik, ödüller aracılığıyla etkiye dayanmaktadır (Pearce vd., 2008). Dönüşümcü liderlikte ve güçlendirici liderlikte liderler izleyenlerine koçluk ve mentorluk edebilir. Ancak bu davranışlar farklı amaçlara hizmet etmektedir. Bu durum dönüşümcü liderlikte lider karizmasını ve lidere olan inancı arttırmaya hizmet ederken; güçlendirici liderlikte, izleyenlerine kendi kendine liderlik becerilerini öğretmeye hizmet etmektedir (Tuckey vd., 2012, s. 18).

Güçlendirici liderlik hiyerarşik kontrol sürecinden çok, çalışanların öz yetkinliği üzerine vurgu yapan bir liderlik yaklaşımıdır. Liderler sınırlı zamana, enerjiye, bilgiye ve yetki alanına sahip olduğundan güçlendirici liderlik biçemini kullanmaya özendirilmelidir. Çalışanlara daha fazla karar verme yetkisi verildikçe daha fazla motive olabilmektedirler (Yun, vd., 2006, s. 378). Güçlendirici liderlik yaklaşımı Arnold vd. (2000) tarafından tanıtılmıştır. Bu liderlik biçemi izleyenlerin güç duygusunu, öz yeterlilik ve öz denetim hislerini arttırma sürecini teşvik eder. Ayrıca güçlendirici liderliğin geleneksel hiyerarşik yönetim yapısının değiştirilmesini kolaylaştırması beklenmektedir (Bobbio vd., 2012, s. 79).

Güçlendirici liderlik çalışanların kendi davranışlarını, öz denetimlerini geliştirmeyi hedefleyen bir liderlik yaklaşımıdır. Bu liderlik yaklaşımı, temel olarak gücün dağıtımında ve paylaşımında lidere reçete sunan bir yaklaşımdır (Liu vd., 2003, s. 133). İzleyenlerine rol model olarak güçlendirici liderler, örgüt çalışanlarının yaratıcı sonuçlara ulaşması, başarı için farklı yollar denemesi ve daha iyi performans için, işlerine olan bağlılıklarıyla ve çalışmalarıyla onlara yol gösterir.

Güçlendirici liderliğe ilişkin yurt dışında yapılan çalışmalarda, güçlendirilen çalışanların örgüte olan bağlılıklarının arttığı, işlerine daha çok motive oldukları ve daha çok doyum yaşadıklarına iliş̧in sonuçlar elde edilmiştir (Albrecht, S. L. ve Andreetta, 2011; Gao vd., 2011; Srivastava vd., 2006). Ancak Türkiye'de özellikle eğitim örgütlerinde güçlendirici lider davranışlarına ilişkin sınılı sayıda (Gümüş, 2013; Koçak, 2016) araştırma yapılmıştır. Bu araştırmalar ise belirli öğrenim basamaklarındaki öğretmenler üzerinde gerçekleştirilmiştir. Günümüzde popüler hale gelen güçlendirici liderliğin eğitim örgütlerinde de ele alınması, bütüncül bir bakış açısıyla mevcut durumun ortaya konması önem arz etmektedir. Ayrıca böyle bir araştırmanın eğitim örgütlerinde güçlendirici liderlik ile farklı değişkenler arasındaki ilişkilere yönelik araştırmaları da teşvik edeceği düşünülmektedir.

İnsan öğesinin belirleyici olduğu, lider ve izleyenlerin bilgi, beceri ve geçmiş yaşantılar açısından birbirlerine yakın yeterliklere sahip olduğu eğitim örgütlerinde güçlendirici liderliğin etkili olması beklenir. Bu beklenti ışı̆̆ında, okul müdürlerinin güçlendirici liderliği ne düzeyde sergilediklerine ilişkin öğretmen algılarının belirlenmesi amacıyla bu çalışma gerçekleştirilmiştir.

Araştırmada aşağıdaki sorulara yanıt aranmıştır:

1. Okul müdürlerinin güçlendirici liderliği sergilemelerine ilişkin öğretmen algıları ne düzeydedir?

2. Okul müdürlerinin güçlendirici liderliği ne düzeyde sergilediklerine ilişkin öğretmen algıları cinsiyet, branş, hizmet süresi (kıdem), mevcut okul müdürüyle çalışma süresi ve görev yaptığı okulun türüne göre anlamlı farklılık göstermekte midir? 


\section{YÖNTEM}

Bu bölümde araştırmanın modeline, evren ve örneklemine, veri toplama aracına ve verilerin analizine yer verilmiştir.

\subsection{Araştırmanın Modeli}

Okul müdürlerinin güçlendirici liderliği ne düzeyde gösterdiklerine ilişkin öğretmen algılarının belirlenmesi amacıyla gerçekleştirilen bu çalışma tarama modelinde bir araştırmadır.

\subsection{Evren ve Örneklem}

Çalışmanın evrenini Malatya Büyükşehir Belediyesi merkez ilçeleri olan Battalgazi ve Yeşilyurt'taki ilkokul, ortaokul ve liselerde görevli 6342 öğretmen oluşturmaktadır. Evrendeki tüm öğretmenlere ulaşmanın zaman ve maddi olanaklar açısından zor olduğu düşünülerek örneklem alma yoluna gidilmiştir. Bu evrenden, evreni temsil eder nitelikte seçkisiz olarak belirlenen, veri toplama aracını gönüllü olarak ve yönergeye uygun biçimde tam ve doğru yanıtlayan 321 öğretmen ise örneklemi oluşturmaktadır.

Araştırmaya katılan öğretmenlerin kişisel bilgilerine ilişkin bilgiler Tablo 1'de verilmiştir.

Tablo 1

Öğretmenlerin Kişisel Bilgileri

\begin{tabular}{llcc}
\hline \multicolumn{1}{c}{ Kişisel Bilgiler } & & $\mathrm{N}$ & $\%$ \\
\hline \multirow{2}{*}{ Cinsiyet } & Kadın & 149 & 46,4 \\
& Erkek & 172 & 53,6 \\
\hline \multirow{3}{*}{ Öğrenim Kurumu } & Ilkokul & 110 & 34,3 \\
& Ortaokul & 105 & 32,7 \\
& Lise & 106 & 33 \\
\hline \multirow{3}{*}{ Hizmet Süresi(kıdem) } & $(1-5)$ yıl & 88 & 27,4 \\
& $(6-10)$ yıl & 76 & 23,7 \\
& $(11-15)$ yıl & 63 & 19,6 \\
& $(16-20)$ yıl & 44 & 13,7 \\
& 21 yıl ve üzeri & 50 & 15,6 \\
\hline \multirow{3}{*}{ Okul Müdürüyle Çalışma Süresi } & 1 yıl & 94 & 29,3 \\
& 2 yıl & 84 & 26,2 \\
& 3 yıl & 82 & 26,2 \\
& 4 yıl ve üzeri & 59 & 18,4 \\
\hline \multirow{2}{*}{ Branş } & Sınıf Öğretmeni & 110 & 34,3 \\
& Branş Öğretmeni & 211 & 65,7
\end{tabular}

Tablo 1'de görüldüğü gibi, araştırmaya katılan öğretmenlerin 146'sı $(\% 46,4)$ kadın, 172 'si $(\% 53,6)$ ise erkektir. Öğretmenlerin 110'u (\%34,3)ü ilkokulda, 105'i $(\% 32,7)$ ortaokulda ve 106 'sı (\%33) ise lisede görev yapmaktadır. Araştırmaya katılan öğretmenlerin $88^{\prime} \mathrm{i}(\% 27,4)$ (1-5) yıl arası, 76'sı (\%23,7) (6-10) yıl arası, 63'ü (\%19,6) (11-15) yıl arası, 44'ü (\%13,7) (16-20) yıl arası, 50'si (\%15,6) 21 yıl ve üzeri hizmet süresine sahiptir. Öğretmenlerin okul müdürüyle çalışma süreleri incelendiğinde $94^{\prime} u ̈(\% 29,3)$ bir yıl, 84'ü $(\% 26,2)$ iki-üç yıl ve 59'u $(\% 18,4)$ ise 4 yıl ve üzeri aynı okul müdürüyle birlikte çalıştığı gözlenmektedir. Öğretmenlerin 110 'u $(\% 34,3)$ sınıf öğretmeni ve $211^{\prime} i(\% 65,7)$ ise branş öğretmeni olarak görev yapmaktadır.

\subsection{Veri Toplama Aracı ve Uygulanması}

Araştırmada veri toplama aracı olarak Konczak, vd. (2000) tarafından geliştirilen, araştırmacılar tarafından eğitim örgütleri için Türkçeye uyarlaması yapılan 17 maddeden oluşan "Güçlendirici Liderlik Ölçeği" kullanılmıştır. Araştırmacılar, ölçeğin eğitim örgütleri için 
Türkçeye uyarlaması sürecinde yaptıkları AFA sonucunda faktör yük değerleri .608 ile .848 arasında değişen üç faktörlü bir yapı elde etmişlerdir. Bu faktörlere ait Cronbach Alpha güvenirlik katsayıları sırasıyla $.76, .82$ ve .80 olarak bulunmuştur. Yapının geçerliğini test etmek için yapılan DFA sonucunda uyum iyiliği değerleri; $\chi^{2} / S d=2,54 ; \mathrm{GFI}=0,92 ; \mathrm{AGFI}=0,90 ; \mathrm{NNFI}=$ 0,$98 ; \mathrm{CFI}=0,98 ; \mathrm{RMSEA}=0,054 ; \mathrm{RMR}=0,043 ; \mathrm{SRMR}=0,045$ olarak hesaplanmıştır. Ayrıca Alt ve üst \%27'lik grupların t-testi sonucunda maddelerin geçerliklerinin yüksek olduğu ve ayırt edici nitelikte olduğu sonucuna ulaşılmıştır.

Güçlendirici Liderlik Ölçeği yetki verme, sorumluluk ve destekleme olmak üzere üç alt boyut ve 17 maddeden oluşmaktadır. Likert tipi beşli derecelendirme biçiminde düzenlenen ölçeğin her bir maddesinin "hiç bir zaman", "nadiren", "ara sıra", "çoğu zaman" veya "her zaman" seçeneklerinden birinin işaretlenerek yanıtlanması beklenmektedir.

Veri toplama aracı iki bölümden oluşmaktadır. Birinci bölümde katılımcıların kişisel özelliklerini belirlemeyi amaçlayan beş madde bulunmaktadır. íkinci bölümde ise öğretmelerin okul müdürlerinin güçlendirici liderlik özelliklerini belirlemeye yönelik maddelere yer verilmiştir.

Veri toplama aracı tüm öğretmenlere görevli bulundukları okullarda araştırmacılar tarafından dağıtılarak toplanmıştır. Uygulama yapılmadan önce araştırmanın amacıyla ilgili katılımcılara bilgi verilmiş ve gönüllü olanların katılımı sağlanmıştır. Veri toplama aracının yanıtlanması 6-9 dakika sürmüştür. Uygulama sonucunda toplam 338 öğretmenden veri elde edilmiştir. Eksik ve hatalı doldurulan 17 (\%6) veri toplama aracı analizlere dahil edilmemiştir. Gerekli analizler 321 veri toplama aracı üzerinden yapılmıştır.

\subsection{Verilerin Analizi}

Elde edilen veriler bilgisayarda SPSS programına girilmiştir. Verilerin analizinde t testi ve tekyönlü varyans analizinden yararlanılmıştır.

\section{BULGULAR}

Okul müdürlerinin güçlendirici liderliği ne düzeyde sergilediklerine ilişkin öğretmen algılarının belirlenmesi amacıyla gerçekleştirilen bu çalışmada yanıtı aranan sorulara ilişkin bulgular aşağıda sırayla verilmiştir.

\section{1. Öğretmen Algılarına Göre Okul Müdürlerinin Güçlendirici Liderliği Sergileme Düzeylerine İlişkin Bulgular}

Okul müdürlerinin güçlendirici liderliği ve alt boyutlarını ne düzeyde sergilediklerine ilişkin öğretmen algıları Tablo 2'de sunulmuştur.

Tablo 2

Okul Müdürlerinin Güçlendirici Liderlik Davranışlarına Iliş̧kin Öğretmen Algıları

\begin{tabular}{lcc}
\hline & $\overline{\mathrm{X}}$ & $\mathrm{N}=321$ \\
\hline Güçlendirici Liderlik & 3,74 & $\mathrm{~S}$ \\
Sorumluluk & 4,05 &, 71 \\
Destekleme & 3,63 &, 72 \\
Yetki Verme & 3,84 &, 86 \\
\hline
\end{tabular}

Tablo 2 incelendiğinde, okul müdürlerinin güçlendirici liderliği ne düzeyde gösterdiklerine ilişkin öğretmen algılarının "çoğu zaman" düzeyine yakın $(\bar{X}=3,74)$ olduğu, başka bir ifadeyle öğretmen algılarına göre okul müdürlerinin yüksek düzeyde güçlendirici liderlik davranışları sergilediği görülmektedir. Öğretmen algılarına göre, okul müdürlerinin güçlendirici liderlik boyutlarından sorumluluk boyutu kapsamında yer alan davranışları daha 
çok sergiledikleri $(\bar{X}=4,05)$, destekleme boyutu kapsamında yer alan davranışları ise en az sergiledikleri $(\bar{X}=3,63)$ tespit edilmiştir. Okul müdürlerinin güçlendirici liderliğine ilişkin yetki verme boyutunda ise öğretmen algılarının $(\bar{X}=3,84)$ düzeyinde olduğu belirlenmiştir.

3.2. Okul Müdürlerinin Güçlendirici Liderliği Ne Düzeyde Sergilediklerine ilişkin Öğretmen Algılarının Cinsiyet, Branş, Hizmet Süresi (Kıdem), Mevcut Okul Müdürüyle Çalışma Süresi ve Görev Yaptığı Okulun Türüne Göre Dağııımına İlişkin Bulgular

Araştırmaya katılan öğretmenlerin okul müdürlerinin güçlendirici liderliği ne düzeyde sergilediklerine ilişkin cinsiyete göre algılarına yönelik bulgular Tablo 3'te verilmiştir.

Tablo 3

Öğretmen Algılarının Cinsiyetlerine Göre Analizi

\begin{tabular}{|c|c|c|c|c|c|c|c|c|}
\hline $\begin{array}{l}\text { Güçlendirici Liderlik ve } \\
\text { Boyutları }\end{array}$ & Cinsiyet & $\mathrm{N}$ & $\bar{x}$ & $S$ & sd & $\mathrm{t}$ & $p$ & $\eta^{2}$ \\
\hline Güçlendirici Liderlik & $\begin{array}{l}\text { Kadın } \\
\text { Erkek }\end{array}$ & $\begin{array}{l}149 \\
172\end{array}$ & $\begin{array}{l}3,61 \\
3,85\end{array}$ & $\begin{array}{l}76 \\
\text {,66 }\end{array}$ & 319 & 2,96 & ,00 & 0,02 \\
\hline Sorumluluk & $\begin{array}{l}\text { Kadın } \\
\text { Erkek }\end{array}$ & $\begin{array}{l}149 \\
172\end{array}$ & $\begin{array}{l}4,02 \\
4,08\end{array}$ & $\begin{array}{l}75 \\
\text {,69 }\end{array}$ & 319 & 695 & ,48 & 0,00 \\
\hline Destekleme & $\begin{array}{l}\text { Kadın } \\
\text { Erkek }\end{array}$ & $\begin{array}{l}149 \\
172\end{array}$ & $\begin{array}{l}3,48 \\
3,75\end{array}$ & $\begin{array}{l}92 \\
, 79\end{array}$ & 319 & 2,86 & , 00 & 0,02 \\
\hline Yetki Verme & $\begin{array}{l}\text { Kadın } \\
\text { Erkek }\end{array}$ & $\begin{array}{l}149 \\
172\end{array}$ & $\begin{array}{l}3,70 \\
3,96\end{array}$ & $\begin{array}{l}96 \\
, 88\end{array}$ & 319 & 2,58 & 01 & 0,02 \\
\hline
\end{tabular}

Tablo 3'teki veriler incelendiğinde, okul müdürlerinin güçlendirici liderliği ne düzeyde sergilediklerine ilişkin öğretmen algılarının cinsiyete göre anlamlı farklılık gösterdiği görülmektedir [t(319)=2,96, $\mathrm{p}<.05]$. Okul müdürlerinin güçlendirici liderliğine ilişkin erkek öğretmenlerin $(\bar{X}=3,85)$ algı ortalamalarının kadın öğretmenlerin $(\bar{X}=3,61)$ algı ortalamalarından daha yüksek olduğu tespit edilmiştir. Güçlendirici liderliğin yetki verme $[\mathrm{t}(319)=2,58, \mathrm{p}<.05]$ ve destekleme $[\mathrm{t}(319)=2,86, \mathrm{p}<.05]$ alt boyutlarına ilişkin öğretmen algılarında da cinsiyete göre istatistiksel olarak anlamlı bir fark görülmektedir. Güçlendirici liderliğin yetki verme $[\operatorname{kad} ı n(\bar{X})=3,70$; erkek $(\bar{X})=3,96$ ] ve destekleme [kadın $(\bar{X})=3,48$; erkek $(\bar{X})=3,75]$ alt boyutlarının her ikisinde de kadın öğretmenlerin algı ortalamalarının erkek öğretmenlerin algı ortalamalarından daha yüksek olduğu belirlenmiştir. Sorumluluk alt boyutunda ise öğretmen algılarında cinsiyete göre anlamlı farklılık görülmemektedir $[\mathrm{t}(319)=, 695, \mathrm{p}<.05]$. Ayrıca eta-kare değerlerinden hareketle güçlendirici liderlik $\left(\eta^{2}=0,02\right)$ ve güçlendirici liderliğin yetki verme $\left(\eta^{2}=0,02\right)$ ve destekleme $\left(\eta^{2}=0,02\right)$ alt boyutlarına ilişkin öğretmenlerin algı ortalamalarındaki farklılaşmada cinsiyetin küçük etki büyüklügüne sahip olduğu söylenebilir.

Araştırmaya katılan öğretmenlerin okul müdürlerinin güçlendirici liderliği ne düzeyde sergilediklerine ilişkin branşlarına göre algılarına yönelik bulgular Tablo 4'te verilmiştir.

Tablo 4

Öğretmen Algılarının Branşlarına Göre Analizi

\begin{tabular}{lllllllll}
\hline Güçlendirici Liderlik ve & Branş & $\mathrm{N}$ & $\overline{\mathrm{X}}$ & $\mathrm{S}$ & $\mathrm{sd}$ & $\mathrm{t}$ & $\mathrm{p}$ & $\eta^{2}$ \\
Boyutları & & & & & & & & \\
\hline Güçlendirici Liderlik & Sınıf & 110 & 3,68 &, 75 & 319 &, 96 &, 33 & 0,00 \\
& Branş & 211 & 3,77 &, 69 & & & & \\
Sorumluluk & Sınıf & 110 & 3,94 &, 78 & 319 & 1,99 &, 04 & 0,01 \\
& Branş & 211 & 4,11 &, 68 & & & & \\
Destekleme & Sınıf & 110 & 3,58 &, 86 & 319 &, 72 &, 47 & 0,00 \\
& Branş & 211 & 3,65 &, 86 & & & \\
Yetki Verme & Sınıf & 110 & 3,82 &, 93 & 319 &, 221 &, 82 & 0,00 \\
\hline
\end{tabular}


Tablo 4'deki veriler incelendiğinde, okul müdürlerinin güçlendirici liderliği ne düzeyde sergilediğine ilişkin öğretmen algılarının branşlarına göre anlamlı farklılık göstermediği görülmektedir $[\mathrm{t}(319)=, 96, \mathrm{p}<.05]$. Güçlendirici liderlik alt boyutlarından yetki verme $[\mathrm{t}(319)=, 221, \mathrm{p}<.05]$ ve destekleme $[\mathrm{t}(319)=, 72, \mathrm{p}<.05]$ alt boyutlarında da öğretmen algılarının branşlarına göre anlamlı farklılık göstermediği görülmektedir. Sorumluluk alt boyutunda ise öğretmen algılarında branşa göre anlamlı bir farklılığın olduğu görülmektedir $[\mathrm{t}(319)=1,99, \mathrm{p}<.05]$. Güçlendirici liderliğinin sorumluluk alt boyutuna ilişkin algı ortalamaları incelendiğinde branş öğretmenlerinin $(\bar{X}=4,11)$ algı ortalamalarının sınıf öğretmenlerinin $(\bar{X}=3,94)$ algı ortalamalarından daha yüksek olduğu belirlenmiştir. Ayrıca eta-kare $\left(\eta^{2}=0,01\right)$ değerinden hareketle sorumluluk alt boyutunda öğretmenlerin algı ortalamalarındaki farklılaşmada branş değişkeninin oldukça küçük bir etki büyüklüğüne sahip olduğu ve pratik açıdan manidarlığın sorgulanabilir olduğu söylenebilir.

Araştırmaya katılan öğretmenlerin okul müdürlerinin güçlendirici liderliği ne düzeyde sergilediklerine ilişkin hizmet sürelerine göre algılarına yönelik bulgular Tablo 5 'te verilmiştir.

Tablo 5

Öğretmen Algılarının Kıdemlerine Göre Analizi

\begin{tabular}{|c|c|c|c|c|c|c|c|c|c|c|c|}
\hline \multirow{5}{*}{ 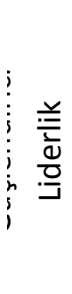 } & $\begin{array}{l}\text { Hizmet } \\
\text { Süresi }\end{array}$ & $\mathrm{N}$ & $\bar{x}$ & $S$ & $\begin{array}{c}\text { Varyansın } \\
\text { Kaynağı }\end{array}$ & $\begin{array}{c}\text { Kareler } \\
\text { Top. }\end{array}$ & sd & $\begin{array}{c}\text { Kareler } \\
\text { Ort. }\end{array}$ & $F$ & $\mathrm{p}$ & $\begin{array}{l}\text { Fark } \\
\text { (LSD) }\end{array}$ \\
\hline & $(1-5)$ yıl & $\begin{array}{l}88 \\
76\end{array}$ & $\begin{array}{l}3,6 \\
3,8\end{array}$ & $\begin{array}{l}12 \\
25\end{array}$ & Gruplararası & 2,006 & 4 & ,501 & ,972 & ,42 & \\
\hline & (11-15) yıl & 63 & 3,7 & ,31 & Gruplarici & 162,93 & 316 & & & & \\
\hline & (16-20) yıl & 44 & 3,6 & ,24 & & & & & & & \\
\hline & 21 yıl ve & 50 & 3,8 &, 44 & Toplam & 164,94 & 320 & & & & \\
\hline \multirow{7}{*}{ 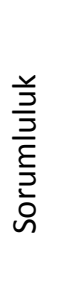 } & Hizmet & $\mathrm{N}$ & $\overline{\mathbf{x}}$ & $\mathrm{S}$ & Varyansın & Kareler & sd & Kareler & $F$ & $\mathrm{p}$ & Fark \\
\hline & Süresi & & & & Kaynağı & Top. & & Ort. & & ק & (LSD) \\
\hline & $(1-5)$ yıl & 88 & 4,0 & ,25 & Gruplararası & ,645 & 4 & 161 & ,303 & ,87 & \\
\hline & (6-10) yıl & 76 & 4,0 & 36 & & & & & & & \\
\hline & (11-15) yıl & 63 & 4,0 & ,45 & Gruplariçi & 167,97 & 316 & & & & \\
\hline & $(16-20)$ yıl & 44 & 4,0 & ,57 & & & & & & & \\
\hline & 21 yıl ve & 50 & 3,9 &, 42 & Toplam & 168,62 & & & & & \\
\hline \multirow{7}{*}{ 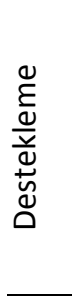 } & Hizmet & $\mathrm{N}$ & $\overline{\mathbf{x}}$ & S & Varyansın & Kareler & $\mathrm{cd}$ & Kareler & $F$ & $n$ & Fark \\
\hline & Süresi & & $\lambda$ & 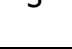 & Kaynağı & Top. & su & Ort. & $r$ & 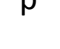 & (LSD) \\
\hline & $(1-5)$ yıl & 88 & 3,5 & ,64 & Gruplararası & 3,295 & 4 & ,824 & 1,096 & ,35 & \\
\hline & $(6-10)$ yıl & 76 & 3,6 &, 42 & & & & & & & \\
\hline & (11-15) yıl & 63 & 3,6 & ,32 & Gruplariçi & 237,61 & 316 & & & & \\
\hline & $(16-20)$ yıl & 44 & 3,5 & 60 & & & & & & & \\
\hline & $21 \mathrm{yıl}$ ve & 50 & 3,8 &, 21 & Toplam & 240,91 & & & & & \\
\hline \multirow{7}{*}{ 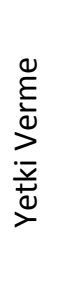 } & Hizmet & $N$ & $\overline{\mathbf{z}}$ & $\mathrm{s}$ & Varyansın & Kareler & cd & Kareler & $F$ & $n$ & Fark \\
\hline & Süresi & IV & $x$ & 3 & Kaynağı & Top. & su & Ort. & $r$ & 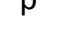 & (LSD) \\
\hline & $(1-5)$ yıl & 88 & 3,7 & ,34 & Gruplararası & 5,305 & 4 & 1,326 & 1,538 & 19 & \\
\hline & $(6-10)$ yıl & 76 & 4,0 &, 62 & & & & & & & \\
\hline & $(11-15)$ yıl & 63 & 3,8 & ,16 & Gruplariçi & 272,46 & 316 & & & & \\
\hline & $(16-20)$ yıl & 44 & 3,7 & ,69 & & & & & & & \\
\hline & 21 yıl ve & 50 & 3,9 & ,79 & Toplam & 277,77 & & & & & \\
\hline
\end{tabular}

Tablo 5'deki veriler incelendiğinde, okul müdürlerinin güçlendirici liderliği ne düzeyde sergilediklerine ilişkin öğretmen algılarının öğretmenlikteki toplam hizmet süresine göre anlamlı farklılık göstermediği görülmektedir $\left[\mathrm{F}_{(4-316)}=, 972, p>.05\right]$. Güçlendirici liderliğin yetki verme $\left[F_{(4-316)}=1,538, p>.05\right]$, sorumluluk $\left[F_{(4-316)}=, 303, p>.05\right]$ ve destekleme $\left[F_{(4-316)}\right.$ $=1,096, p>.05$ ] alt boyutlarına ilişkin öğretmen algılarında da hizmet süresine göre istatistiksel olarak anlamlı bir farklılığın olmadığı görülmektedir. 
Araştırmaya katılan öğretmenlerin okul müdürlerinin güçlendirici liderliği ne düzeyde sergilediklerine ilişkin okul müdürüyle çalışma süresine göre algılarına yönelik bulgular Tablo $6^{\prime}$ da verilmiştir.

Tablo 6

Öğretmen Algılarının Mevcut Okul Müdürüyle Çalışma Süresine Göre Analizi

\begin{tabular}{|c|c|c|c|c|c|c|c|c|c|c|c|}
\hline $\begin{array}{l}\frac{2}{\bar{y}} \\
\frac{0}{0} \\
\frac{0}{3}\end{array}$ & $\begin{array}{l}\text { Müdürle } \\
\text { Çalışma } \\
\text { Süresi }\end{array}$ & $N$ & $\bar{x}$ & $S$ & $\begin{array}{c}\text { Varyansın } \\
\text { Kaynağı }\end{array}$ & $\begin{array}{c}\text { Kareler } \\
\text { Top. }\end{array}$ & sd & $\begin{array}{c}\text { Kareler } \\
\text { Ort. }\end{array}$ & $\mathrm{F}$ & $p$ & $\begin{array}{l}\text { Fark } \\
\text { (LSD) }\end{array}$ \\
\hline 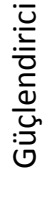 & $\begin{array}{l}1 \text { yıl } \\
2 \text { yıl } \\
3 \text { yıl } \\
4 \text { yıl ve üzeri }\end{array}$ & $\begin{array}{l}94 \\
84 \\
84 \\
59\end{array}$ & $\begin{array}{l}3,8 \\
3,5 \\
3,7 \\
3,8\end{array}$ & $\begin{array}{l}46 \\
, 52 \\
39 \\
, 48\end{array}$ & $\begin{array}{l}\text { Gruplariçi } \\
\text { Toplam }\end{array}$ & $\begin{array}{l}5,853 \\
159,09 \\
16 \hat{,}, 94\end{array}$ & $\begin{array}{c}3 \\
317 \\
320\end{array}$ & $\begin{array}{l}1,951 \\
, 502\end{array}$ & 3,887 & ,00 & $\begin{array}{l}1-2 \\
2-4\end{array}$ \\
\hline 兰 & $\begin{array}{l}\text { Müdürle } \\
\text { Çalışma } \\
\text { Süresi }\end{array}$ & $\mathrm{N}$ & $\bar{x}$ & $S$ & $\begin{array}{c}\text { Varyansın } \\
\text { Kaynağı }\end{array}$ & $\begin{array}{c}\text { Kareler } \\
\text { Top. }\end{array}$ & sd & $\begin{array}{c}\text { Kareler } \\
\text { Ort. }\end{array}$ & $F$ & $p$ & $\begin{array}{l}\text { Fark } \\
\text { (LSD) }\end{array}$ \\
\hline 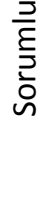 & $\begin{array}{l}1 \text { yıl } \\
2 \text { yıl } \\
3 \text { yıl } \\
4 \text { yıl ve üzeri }\end{array}$ & $\begin{array}{l}94 \\
84 \\
84 \\
59\end{array}$ & $\begin{array}{l}4,0 \\
4,0 \\
3,9 \\
4,1\end{array}$ & $\begin{array}{l}, 24 \\
, 35 \\
42 \\
, 28\end{array}$ & $\begin{array}{c}\text { Gruplararası } \\
\text { Gruplariçi } \\
\text { Toplam }\end{array}$ & $\begin{array}{l}2,656 \\
275,11 \\
27 \overline{7,77}\end{array}$ & $\begin{array}{c}3 \\
317 \\
320\end{array}$ & $\begin{array}{l}, 665 \\
, 526\end{array}$ & 1,264 & 28 & \\
\hline$\stackrel{\varrho}{\varepsilon}$ & $\begin{array}{l}\text { Müdürle } \\
\text { Çalışma } \\
\text { Süresi }\end{array}$ & $\mathrm{N}$ & $\bar{x}$ & $S$ & $\begin{array}{c}\text { Varyansın } \\
\text { Kaynağı }\end{array}$ & $\begin{array}{c}\text { Kareler } \\
\text { Top. }\end{array}$ & $\mathrm{sd}$ & $\begin{array}{c}\text { Kareler } \\
\text { Ort. }\end{array}$ & $F$ & $p$ & $\begin{array}{l}\text { Fark } \\
\text { (LSD) }\end{array}$ \\
\hline 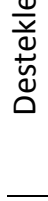 & $\begin{array}{l}1 \text { yıl } \\
2 \text { yıl } \\
3 \text { yıl } \\
4 \text { yıl ve üzeri }\end{array}$ & $\begin{array}{l}94 \\
84 \\
84 \\
59\end{array}$ & $\begin{array}{l}3,7 \\
3,3 \\
3,6 \\
3,6\end{array}$ & $\begin{array}{l}, 62 \\
, 53 \\
60 \\
48\end{array}$ & $\begin{array}{c}\text { Gruplararası } \\
\text { Gruplariçi } \\
\text { Toplam }\end{array}$ & $\begin{array}{l}9,921 \\
230,99 \\
240,91\end{array}$ & $\begin{array}{c}3 \\
317 \\
320 \\
\end{array}$ & $\begin{array}{r}3,307 \\
, 729\end{array}$ & 4,538 & ,00 & $\begin{array}{l}1-2 \\
2-4\end{array}$ \\
\hline$\stackrel{\bigotimes}{E}$ & $\begin{array}{l}\text { Müdürle } \\
\text { Çalışma } \\
\text { Süresi }\end{array}$ & $\mathrm{N}$ & $\bar{x}$ & $S$ & $\begin{array}{c}\text { Varyansın } \\
\text { Kaynağı }\end{array}$ & $\begin{array}{c}\text { Kareler } \\
\text { Top. }\end{array}$ & $s d$ & $\begin{array}{c}\text { Kareler } \\
\text { Ort. }\end{array}$ & $F$ & $p$ & $\begin{array}{l}\text { Fark } \\
\text { (LSD) }\end{array}$ \\
\hline$\frac{\bar{d}}{\stackrel{\bar{x}}{+\frac{d}{d}}}$ & $\begin{array}{l}1 \text { yıl } \\
2 \text { yıl } \\
3 \text { yıl } \\
4 \text { yıl ve üzeri }\end{array}$ & $\begin{array}{l}94 \\
84 \\
84 \\
59\end{array}$ & $\begin{array}{l}3,8 \\
3,7 \\
3,8 \\
3,9\end{array}$ & $\begin{array}{l}77 \\
52 \\
, 62 \\
45\end{array}$ & $\begin{array}{c}\text { Gruplararası } \\
\text { Gruplariçi } \\
\text { Toplam }\end{array}$ & $\begin{array}{l}5,305 \\
272,46 \\
27 \hat{7,77}\end{array}$ & $\begin{array}{c}3 \\
317 \\
320\end{array}$ & $\begin{array}{l}, 885 \\
, 868\end{array}$ & 1,020 & ,38 & \\
\hline
\end{tabular}

Tablo 6 incelendiğinde, okul müdürlerinin güçlendirici liderliği ne düzeyde gösterdiklerine ilişkin öğretmen algılarının mevcut okul müdürüyle çalışma süresine göre anlamlı farklılık gösterdiği görülmektedir $\left[\mathrm{F}_{(3-317)}=3,887, \mathrm{p}<.05\right]$. Anlamlı farklıığın hangi gruplar arasında olduğunu belirlemek amacıyla yapılan LSD testi sonucunda güçlendirici liderliğe ilişkin öğretmen algılarındaki farklılığın okul müdürüyle 1 yıl ve 2 yıl ile 2 yıl ve 4 yıl çalışma süresine sahip öğretmenler arasında olduğu belirlenmiştir. Aritmetik ortalamalar incelendiğinde, mevcut okul müdürüyle 1 yıl $((\bar{X}=3,85)$ ve 4 yıl $(\bar{X}=3,85)$ çalışma süresine sahip öğretmenlerin algı ortalamalarının mevcut okul müdürüyle 2 yıl $(\bar{X}=3,52)$ çalışma süresine sahip öğretmenlerin algı ortalamalarından daha yüksek olduğu tespit edilmiştir. Ayrıca hesaplanan eta-kare $\left(\eta^{2}=0,03\right)$ değerinden hareketle okul müdürlerinin güçlendirici liderliğine ilişkin öğretmen algılarındaki farklılaşmada mevcut okul müdürüyle çalışma süresinin küçük etki büyüklüğüne sahip olduğu söylenebilir. Güçlendirici liderliğin destekleme alt boyutunda da mevcut okul müdürüyle çalışma süresine göre öğretmen algılarında anlamlı farklılık görülmektedir $\left[F_{(3-317)}\right.$ $=4,538, p<.05]$. Anlamlı farklılığın hangi gruplar arasında olduğunu belirlemek amacıyla yapılan 
LSD testi sonucunda destekleme alt boyutuna ilişkin öğretmen algılarındaki farklılığın okul müdürüyle 1 yıl ve 2 yıl ile 2 yıl ve 4 yıl çalışma süresine sahip öğretmenler arasında olduğu belirlenmiştir. Aritmetik ortalamalar incelendiğinde destekleme alt boyutunda mevcut okul müdürüyle 1 yıl $(\bar{X}=3,79)$ ve 4 yıl $(\bar{X}=3,66)$ çalışma süresine sahip öğretmenlerin algı ortalamalarının mevcut okul müdürüyle 2 yıl $(\bar{X}=3,34)$ çalışma süresine sahip öğretmenlerin algı ortalamalarından daha yüksek olduğu belirlenmiştir. Ayrıca destekleme alt boyutu için hesaplanan eta-kare $\left(\eta^{2}=0,04\right)$ değerinden hareketle öğretmen algılarındaki farklılaşmada mevcut okul müdürüyle çalışma süresinin orta düzeyde etki büyüklüğüne sahip olduğu söylenebilir. Güçlendirici liderliğin sorumluluk $\left[F_{(3-317)}=1,264, p>.05\right]$ ve yetki verme $\left[F_{(3-317)}\right.$ $=1,020, p>.05$ ] alt boyutlarında ise mevcut okul müdürüyle çalışma süresine göre öğretmen algılarının farklılık göstermediği görülmektedir.

Araştırmaya katılan öğretmenlerin okul müdürlerinin güçlendirici liderliği ne düzeyde sergilediklerine ilişkin görev yaptığı öğrenim kurumuna göre algılarına yönelik bulgular Tablo 7'de verilmiştir.

Tablo 7

Öğretmen Algılarının Görev Yaptığı Öğrenim Kurumuna Göre Analizi

\begin{tabular}{|c|c|c|c|c|c|c|c|c|c|c|c|}
\hline$\vdots$ 兰 & $\begin{array}{l}\text { Öğrenim } \\
\text { Kurumu }\end{array}$ & $\mathrm{N}$ & $\bar{x}$ & $S$ & $\begin{array}{c}\text { Varyansın } \\
\text { Kaynağı }\end{array}$ & $\begin{array}{c}\text { Kareler } \\
\text { Top. }\end{array}$ & sd & $\begin{array}{c}\text { Kareler } \\
\text { Ort. }\end{array}$ & $F$ & $p$ & $\begin{array}{l}\text { Fark } \\
\text { (LSD) }\end{array}$ \\
\hline i. & $\begin{array}{l}\text { Illkokul } \\
\text { Ortaokul } \\
\text { Lise }\end{array}$ & $\begin{array}{l}110 \\
105 \\
106\end{array}$ & $\begin{array}{l}3,7 \\
3,7 \\
3,7\end{array}$ & $\begin{array}{l}, 52 \\
, 71 \\
63\end{array}$ & $\begin{array}{c}\text { Gruplararası } \\
\text { Gruplariçi } \\
\text { Toplam } \\
\end{array}$ & $\begin{array}{c}, 392 \\
164,55 \\
164,94 \\
\end{array}$ & 318 & $\begin{array}{l}796 \\
, 517\end{array}$ & 379 & 68 & \\
\hline 兰 & $\begin{array}{l}\text { Öğrenim } \\
\text { Kurumu }\end{array}$ & $\mathrm{N}$ & $\bar{x}$ & $S$ & $\begin{array}{l}\text { Varyansın } \\
\text { Kaynağı }\end{array}$ & $\begin{array}{c}\text { Kareler } \\
\text { Top. }\end{array}$ & $s d$ & $\begin{array}{c}\text { Kareler } \\
\text { Ort. }\end{array}$ & $F$ & $p$ & $\begin{array}{l}\text { Fark } \\
\text { (LSD) }\end{array}$ \\
\hline $\begin{array}{l}\frac{\partial}{E} \\
\frac{\mathfrak{D}}{2} \\
\stackrel{0}{0}\end{array}$ & $\begin{array}{l}\text { Illkokul } \\
\text { Ortaokul } \\
\text { Lise }\end{array}$ & $\begin{array}{l}110 \\
105 \\
106\end{array}$ & $\begin{array}{l}3,9 \\
3,8 \\
4,2\end{array}$ & $\begin{array}{l}, 32 \\
, 18 \\
25\end{array}$ & $\begin{array}{c}\text { Gruplararası } \\
\text { Gruplariçi } \\
\text { Toplam }\end{array}$ & $\begin{array}{c}4,123 \\
164,79 \\
168,62\end{array}$ & $\begin{array}{c}2 \\
318\end{array}$ & $\begin{array}{r}2,062 \\
, 517\end{array}$ & 3,986 & ,02 & $2-3$ \\
\hline$\stackrel{\Perp}{\varepsilon}$ & $\begin{array}{l}\text { Öğrenim } \\
\text { Kurumu }\end{array}$ & $\mathrm{N}$ & $\bar{x}$ & $S$ & $\begin{array}{l}\text { Varyansın } \\
\text { Kaynağı }\end{array}$ & $\begin{array}{c}\text { Kareler } \\
\text { Top. }\end{array}$ & sd & $\begin{array}{c}\text { Kareler } \\
\text { Ort. }\end{array}$ & $\mathrm{F}$ & $p$ & $\begin{array}{l}\text { Fark } \\
\text { (LSD) }\end{array}$ \\
\hline 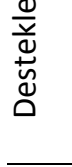 & $\begin{array}{l}\text { İlkokul } \\
\text { Ortaokul } \\
\text { Lise }\end{array}$ & $\begin{array}{l}110 \\
105 \\
106\end{array}$ & $\begin{array}{l}3,6 \\
3,7 \\
3,5\end{array}$ & $\begin{array}{l}, 26 \\
, 35 \\
, 42\end{array}$ & $\begin{array}{c}\text { Gruplararası } \\
\text { Gruplariçi } \\
\text { Toplam }\end{array}$ & $\begin{array}{l}1,505 \\
239,40 \\
240,91 \\
\end{array}$ & 318 & $\begin{array}{l}, 752 \\
753\end{array}$ & 999 & 36 & \\
\hline$\stackrel{\varrho}{\xi}$ & $\begin{array}{l}\text { Öğrenim } \\
\text { Kurumu }\end{array}$ & $\mathrm{N}$ & $\bar{x}$ & $S$ & $\begin{array}{c}\text { Varyansın } \\
\text { Kaynağı }\end{array}$ & $\begin{array}{c}\text { Kareler } \\
\text { Top. }\end{array}$ & $s d$ & $\begin{array}{c}\text { Kareler } \\
\text { Ort. }\end{array}$ & $F$ & $p$ & $\begin{array}{l}\text { Fark } \\
\text { (LSD) }\end{array}$ \\
\hline 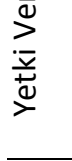 & $\begin{array}{l}\text { Illkokul } \\
\text { Ortaokul } \\
\text { Lise }\end{array}$ & $\begin{array}{l}110 \\
105 \\
106\end{array}$ & $\begin{array}{l}3,8 \\
3,8 \\
3,7\end{array}$ & $\begin{array}{l}, 54 \\
, 62 \\
, 65\end{array}$ & $\begin{array}{c}\text { Gruplariçi } \\
\text { Toplam }\end{array}$ & $\begin{array}{l}276,77 \\
277,77\end{array}$ & $\begin{array}{c}2 \\
318\end{array}$ & $\begin{array}{l}\text {,388 } \\
, 871\end{array}$ & ,445 & 64 & \\
\hline
\end{tabular}

Tablo 7 incelendiğinde, okul müdürlerinin güçlendirici liderliği ne düzeyde sergilediklerine ilişkin öğretmen algılarının görev yaptığı öğrenim kurumuna göre anlamlı farklılık göstermediği görülmektedir $\left[\mathrm{F}_{(2-318)}=, 379, p>.05\right]$. Okul müdürlerinin güçlendirici liderliğine ilişkin destekleme $\left[F_{(2-318)}=, 999, p>.05\right]$ ve yetki verme $\left[F_{(2-318)}=, 445, p>.05\right]$ alt boyutlarında da öğretmen algılarının görev yaptığı öğrenim kurumuna göre anlamlı farklılık göstermediği görülmektedir. Okul müdürlerinin güçlendirici liderliğine ilişkin sorumluluk alt boyutunda ise öğretmen algılarının görev yaptığı öğrenim kurumuna göre anlamlı farklılık gösterdiği görülmektedir $\left[\mathrm{F}_{(2-318)}=3,986, \mathrm{p}<.05\right]$. Anlamlı farklılığın hangi gruplar arasında olduğunu belirlemek amacıyla yapılan LSD testi sonucunda sorumluluk alt boyutuna ilişkin öğretmen algılarındaki farklılı̆ın ortaokul ve lisede görev yapan öğretmenler arasında oluğu 
tespit edilmiştir. Aritmetik ortalamalar incelendiğinde güçlendirici liderliğin sorumluluk alt boyutuna ilişkin lisede görev yapan öğretmenlerin $(\bar{X}=4,21)$ ortaokulda görev yapan öğretmenlerden $(\bar{X}=3,95)$ daha yüksek algı ortalamalarına sahip olduğu belirlenmiştir. Ayrıca sorumluluk alt boyutu için hesaplanan eta-kare $\left(\eta^{2}=0,02\right)$ değerinden hareketle öğretmen algılarındaki farklılaşmada görev yapılan öğrenim kurumunun küçük etki büyüklüğüne sahip olduğu söylenebilir.

\section{SONUÇ, TARTIŞMA VE ÖNERILER}

Türk Eğitim Sistemi merkezi bir yapıya sahiptir. Merkezden yönetimin daha da güçlendirilmesinin, karmaşık örgüt ve çevre ortamlarında varlığını sürdüren okul örgütleri için başarıyı da getirebileceğini söylemek zordur. Eğitimde fonksiyonel kurumlar okullar olup eğitim ve öğretimin doğrudan uygulandığı, öğrencilerin eğitim gördüğü, bizzat somut uygulamaların yapıldığı yerler okullardır (Cafoğlu, 1995). Okulların örgütsel amaçlara ulaşmasında ise öğretmen ve güçlü okul liderleri en önemli faktörler olarak ele alınmaktadır. Dolayısıyla karmaşık örgüt ve çevre koşullarına karşılık başta okul müdürleri olmak üzere öğretmenlerin güçlendirilmesinin yönetim anlayışı olarak daha olumlu sonuçlar doğurabileceğini söylemek mümkündür. Bu kapsamda öğretmenlerin güçlendirilmesinde ise en önemli sorumluluk güçlendirici liderler olarak okul müdürlerine düşmektedir.

Güçlendirici lider davranışlarına yönelik farklı örgütlerde çok sayıda araştırma yapılmasına rağmen okul örgütlerinde bu alanda yeterince araştırma yapılmadığı söylenebilir. Bu bağlamda araştırmada okul müdürlerinin güçlendirici liderliği ne düzeyde sergilediğine ilişkin öğretmen algıları ele alınmıştır. Araştırma sonucunda, öğretmen algılarına göre okul müdürlerinin yüksek düzeyde güçlendirici liderlik davranışları sergilediği, okul müdürlerinin güçlendirici liderlik boyutlarından sorumluluk boyutu kapsamında yer alan davranışları daha çok sergiledikleri en az ise destekleme boyutu kapsamında yer alan davranışları sergilediği belirlenmiştir. Koçak (2016) tarafından yapılan araştırmada da okul yöneticilerinin güçlendirici liderliğine ilişkin öğretmen algılarının yüksek düzeyde olduğu sonucuna ulaşılmıştır. Okul müdürlerinin güçlendirici liderliğine ilişkin öğretmen algılarının yüksek düzeyde olması, okul müdürlerinin güçlendirici liderler olarak öğretmenlerin kendi başına karar verme, problem çözme gibi becerilerini geliştirmeye yönelik davranışlar sergilediği şeklinde de yorumlanabilir. Bu bağlamda piramidin en aşağısında ama öğrencilere en yakın örgüt çalışanları olarak öğretmenlerin problemlere hızlı ve yaratıcı çözümler üretmesine, sorumluluk almalarına güçlendirici liderliğin katkı sağlayacağı söylenebilir.

Araştırmada güçlendirici liderliğin sorgulama alt boyutunda öğretmen algılarının daha yüksek destekleme alt boyutunda ise daha düşük olduğu sonucuna ulaşılmıştır. Bu araştırmada olduğu gibi Gümüş (2013) tarafından yapılan araştırmada da okul müdürlerinin güçlendirici liderliğine ilişkin öğretmenlerin algı ortalamalarının en yüksek sorumluluk alt boyutunda en az ise destekleme alt boyutunda olduğu sonucuna ulaşılmıştır. Öğrencilerle birebir iletişim halinde olmaları, öğrenci başarısında ve okul etkililiğinde önemli bir faktör olması sebebiyle öğretmenlere büyük sorumluluk düşmektedir. Bu bağlamda okul müdürlerinin öğretmenlerin sorumluluk almalarına dönük yüksek düzeyde güçlendirici lider davranışları sergilemeleri olasıdır. Ancak sorumluluk alt boyutuna ilişkin algı ortalamaları yüksekken destekleme alt boyutunda öğretmen algılarının daha düşük düzeyde olması dikkat çekici bir sonuç olarak değerlendirilmektedir.

Okul müdürlerinin güçlendirici liderliği ne düzeyde sergilediklerine ilişkin olarak araştırmaya katılan öğretmenlerin cinsiyetleri bakımından bir farklılaşma gözlenmiştir. Araştırma bulguları erkek öğretmenlerin kadın öğretmenlerle karşılaştırıldığında okul müdürlerinin güçlendirici liderliğine ilişkin algılarının daha yüksek olduğu görülmektedir. 
Benzer şekilde destekleme ve yetki verme alt boyutlarında da erkekler lehine cinsiyete göre anlamlı farklılık olduğu tespit edilmiştir. İlgili araştırmalarda da okul müdürlerinin güçlendirici liderliğine ilişkin öğretmen algılarının cinsiyete göre anlamlı farklılık gösterdiği sonuçlarına ulaşılmıştır (Koçak, 2016; Odabaş, 2014). Okul müdürlerinin güçlendirici liderlik sergilemeleri sürecinde öğretmenlere koçluk etmeleri beklenmektedir. Bu süreçte cinsiyetin, iletişim sürecini ve destek algısını etkileyeceği düşünülmektedir. Okul yöneticilerinin büyük çoğunluğunun erkeklerden oluştuğu da göz önüne alındığında, bu faktörlerin erkekler lehine bir farklılığa sebep olabileceği söylenebilir.

Branş değişkeni açısından değerlendirildiğinde güçlendirici liderliğe ve güçlendirici liderliğin destekleme ve yetki verme boyutuna ilişkin öğretmen algılarında anlamlı bir farklılık görülmezken, sorumluluk boyutunda branş öğretmenleri lehine öğretmen algılarında anlamlı bir farklılığın olduğu sonucuna ulaşılmıştır. Ancak bu farklılı̆a ilişkin eta-kare değeri manidarlığı sorgulanabilecek derecede düşük çıkmışır. İlgili bir çok araştırma (Gümüş, 2013; Kıral, 2015; Koçak, 2016) da okul müdürlerinin güçlendirici liderliğine ilişkin branş değişkenine göre anlamlı farklılı̆̆ın olmadığı sonucuna ulaşıımıştır.

Öğretmenlerin hizmet süresine (kıdem) göre ise okul müdürlerinin güçlendirici liderliği ve alt boyutlarını ne düzeyde sergilediklerine ilişkin öğretmen algılarının anlamlı derecede farklılaşmadığı sonucuna ulaşılmıştır. Kıral (2015), Gümüş (2013) ve Koçak (2016) tarafından yapılan araştırmada öğretmenlikteki hizmet süresine (kıdem) göre anlamlı farklılığa rastlanırken, Odabaş (2014) tarafından yapılan araştırmada okul müdürlerinin güçlendirici liderliğine ilişkin öğretmen algılarında anlamlı bir farklılı̆ın olmadığı sonucuna ulaşılmıştır. Güçlendirici liderlik davranışları daha çok okul yöneticisinin yönetim ve liderlik tarzına bağlı olarak ortaya çıktığından, öğretmenlikteki hizmet süresinden çok okul müdürüyle çalışma süresinin öğretmen algılarında daha belirleyici olacağı söylenebilir.

Öğretmenlerin mevcut okul müdürüyle çalışma süresine göre okul müdürlerinin güçlendirici liderliğine ve destekleme alt boyutuna ilişkin algılarının çalışma süresi $1 y ı l, 4$ yıl ve üzeri olanlar lehine anlamlı derecede farklılaştığı gözlenmiştir. Bunun nedeni, mevcut okul müdürüyle çalışma süresi az olan öğretmenlerin, göreve yeni başlamaları sebebiyle sosyalleşmeleri ve okulun amaçlarını benimsemeleri için okul müdürlerinin güçlendirme bağlamında teşvik edici davranışları olabilir. Okul müdürünün göreve yeni başlamış olması durumunda da yapıyı kurma ve anlayış gösterme çerçevesinde okul müdürlerinin davranışlarının öğretmen algılarını olumlu yönde etkileyebileceği düşünülebilir. Mevcut okul müdürüyle çalışma süresi dört yıl ve üzeri olan öğretmenlerin güçlendirici liderliğe ve destekleme alt boyutuna ilişkin algılarının yüksek olması ise okul müdürlerinin yakından tanıması sebebiyle bu tür öğretmenlere görevlerinde daha fazla otonomi sunmasına bağlanabilir.

Görev yaptığı öğrenim kurumuna göre ise okul müdürlerinin güçlendirici liderliğine ilişkin öğretmen algıları anlamlı düzeyde farklılaşmazken sadece sorumluluk alt boyutunda öğretmen algılarının anlamlı düzeyde farklılaştığı sonucuna ulaşılmıştır. Algı ortalamaları incelendiğinde lisede görev yapan öğretmenlerin ortaokulda görev yapan öğretmenlere göre sorumluluk daha yüksek algı ortalamalarına sahip olduğu görülmektedir. Koçak (2016) tarafından yapılan araştırmada da benzer sonuçlara ulaşıımıştır.

$\mathrm{Bu}$ çalışmada okul müdürlerinin güçlendirici liderliğine ve alt boyutlarına ilişkin öğretmen algıları belirlenmeye çalışılmıştır. Güçlendirici liderliğe ilişkin okul örgütlerinde yurt içinde sınırlı sayıda araştırma olmakla birlikte yurt dışında yapılan araştırmalarda güçlendirici liderliğin; iş doyumu, motivasyon, iş stresi, öğretmen bağlılı̆ı, örgütsel vatandaşlık davranışı, uyum ve okul müdürüyle çatışma gibi birçok örgütsel davranışla ilişkili olduğu sonucuna 
ulaşılmıştır (Bogler ve Somech, 2004; Davis ve Wilson, 2000; Jhonson, 1998). Bu bağlamda okul müdürlerinin güçlendirici liderliğinin, farklı örgütsel ve kişisel faktörlerle olan ilişkisinin araştırılması alana katkı sağlayabilir.

\section{KAYNAKLAR}

Ahearne, M., Mathieu, J. vd. (2005). To empower or not to empower your sales force? An empirical examination of the influence of leadership empowerment behavior on customer satisfaction and performance. Journal of Applied Psychology, 90(5), 945.

Albrecht, S. L. ve Andreetta, M. (2011). The influence of empowering leadership, empowerment and engagement on affective commitment and turnover intentions in community health service workers: Test of a model. Leadership in Health Services, 24(3), 228-237.

Arnold, A.J. Arad, S. vd. (2000). The empowering leadership questionnaire the constranction and validation of a new scale for measuring leader behaviors. Journal of Organizational Behavior. 21, 249-269.

Ayik, A. ve Şayir, G. (2014). Okul müdürlerin öğretimsel liderlik davranişlari ile örgüt iklimi arasindaki ilişki. Electronic Journal Of Social Sciences, 13(49), 253-279

Cafoğlu, Z. (1995). Okulların güçlendirilmesi. Kuram ve Uygulamada Eğitim Yönetimi Dergisi, 1(4), 549-556.

Conger, J. A., ve Kanungo, R. N. (1988). The empowerment process: Integrating theory and practice. Academy of management review, 13(3), 471-482.

Gao, L., Janssen, O. vd. (2011). Leader trust and employee voice: The moderating role of empowering leader behaviors. The Leadership Quarterly,22(4), 787-798.

Davis, J. ve Wilson, S. M. (2000). Principals' efforts to empower teachers: Effects on teacher motivation and job satisfaction and stress. The clearing house, 73(6), 349-353.

Gümüş, A. (2013). Illkokul yöneticilerinde güçlendirici liderlik davranışları ile öğretmenlerde örgütsel bağlılık ilişkisi: Psikolojik güçlendirmenin aracılık rolü (Ankara ili örneği). Yayınlanmamış yüksek lisans tezi, Gazi Üniversitesi, Ankara.

Johnson, P. E. ve Short, P. M. (1998). Principal's leader power, teacher empowerment, teacher compliance and conflict. Educational Management ve Administration, 26(2), 147-159.

Jung, D. I. ve Sosik, J. J. (2002). Transformational leadership in work groups the role of empowerment, cohesiveness, and collective-efficacy on perceived group performance. Small group research, 33(3), 313-336.

Kıral, B. (2015). Lise yöneticilerinin öğretmenleri güçlendirmesi ve öğretmenlerin kayıtsızlık (sinizm) davranışı ile ilişkisi. Yayınlanmamış doktora tezi, Ankara Üniversitesi, Ankara.

Koçak, S. (2016). Ortaöğretim kurumlarındaki psikolojik sözleşme üzerinde güçlendirici liderlik davranışlarının rolü. Yayınlanmamış doktora tezi, Hacettepe Üniversitesi, Ankara.

Konczak, L. J., Stelly, D. J. vd. (2000). Defining and measuring empowering leader behaviors: Development of an upward feedback instrument. Educational and Psychological Measurement, 60(2), 301-313.

Kuo, R. Z., Lai, M. F. vd. (2011). The impact of empowering leadership for KMS adoption. Management Decision, 49(7), 1120-1140. 
Liu, W., Lepak, D. P. vd. (2003). Matching leadership styles with employment modes: strategic human resource management perspective. Human resource management review, 13(1), 127-152.

Magni, M. ve Maruping, L. M. (2013). Sink or Swim: Empowering leadership and overload in teams' ability to deal with the unexpected. Human Resource Management, 52(5), 715739.

Manz, C. C. ve Sims Jr, H. P. (1987). Leading workers to lead themselves: The external leadership of self-managing work teams. Administrative Science Quarterly, 12(4), 106129.

Odabaş, ì. (2014). Yapısal güçlendirme ile örgütsel bağlıık arasındaki ilişkide psikolojik güçlendirmenin ara değişken rolü: öğretmenler üzerinde bir çalışma. Yayınlanmamış yüksek lisans tezi, İstanbul Kültür Üniversitesi, İstanbul.

Pearce, C. L., Conger, J. A. vd. (2008). Shared leadership theory. The Leadership Quarterly, 19(5), 622-628.

Srivastava, A., Bartol, K. M. vd. (2006). Empowering leadership in management teams: Effects on knowledge sharing, efficacy, and performance. Academy of Management Journal, 49(6), 1239-1251.

Şenel, T. ve Buluç, B. (2016). ilkokullarda okul iklimi ile okul etkililiği arasındaki ilişki. Tübav Bilim Dergisi, 9(4), 1-12.

Tuckey, M. R., Bakker, A. B. vd. (2012). Empowering leaders optimize working conditions for engagement: a multilevel study. Journal of Occupational Health Psychology, 17(1), 15.

Yılmaz, H. (2011). Güçlendirici Liderlik. İstanbul: Beta Basım Yayın Dağııım.

Yun, S., Cox, J. vd. (2006). The forgotten follower: a contingency model of leadership and follower self-leadership. Journal of Managerial Psychology, 21(4), 374-388. 


\section{SUMMARY}

It is expected that empowering leadership can be the best for school organizations in which human capital is the pioneering figure and both leader and his followers have similar information, capabilities and past experiences. This study has been done in order to determine to teachers' perceptions on the degree school heads' empowering leadership roles prior to this so called expectation.

This study, conducted to reveal teachers' perceptions on school heads' empowering leadership behaviors, has been designed in survey method. Our research universe consists of 6342 teachers teaching at schools with primary and secondary degrees located in central boroughs, Battalgazi and Yeşilyurt, of Malatya province. Considering that reaching all these teachers is difficult because of time and financial issues, it has been preferred to take a sample from this large universe. Thus, 321 teachers who have been selected randomly and representing the whole universe, answered data collecting tool eagerly and true, are the sample for this study. Our data collecting tool is the "Empowering Leadership Scale" with 17 items developed by Konczak et al (2000) which has been adapted in Turkish by us.

As a result, prior to teachers' perceptions, it has been found that school heads highly act empowering leadership behaviors; they mostly show "responsibility" one of the sub-scales while their least behaviors are those in "assisting sub-scale". It can be said that male teachers compared with females have higher perceptions for school heads' empowering leadership roles.

However, it has been found that teachers' perceptions do not differ according to their length of teaching experience but, there is a significant difference according to total time of working together in which teachers' perceptions differ for the advantage of those who are working together for 4 years and more. On the other hand it has been found that teachers' perceptions do not differ according to school type while only "responsibility sub-scale" significantly differs.

The perceptions of teachers' for school heads' empowering leadership role and sub-scales has been tried to be revealed within this study. There is a limited number of studies related to empowering leadership in our country. Thus it can be recommended to research empowering leadership together with different organizational and personal factors. 